\title{
Tolerance of Caladium Cultivars Florida Cardinal and Florida Fantasy to Sulfonylurea Herbicides
}

\author{
Jialin Yu and Nathan S. Boyd ${ }^{1}$ \\ Department of Horticulture, Gulf Coast Research and Education Center, \\ University of Florida, Wimauma, FL 33598
}

Additional index words. application rate, caladium tuber, postemergence herbicide, weed management

\begin{abstract}
There is a need to identify postemergence (POST) herbicides for weed control in field-grown caladium [Caladium bicolor (Aiton) Vent.]. The objective of this research was to evaluate the tolerance of two caladium cultivars Florida Cardinal and Florida Fantasy to POST applications of sulfonylurea (SU) herbicides flazasulfuron, foramsulfuron, imazosulfuron, and mesosulfuron. At 8 weeks after treatment (WAT), 'Florida Cardinal' and 'Florida Fantasy' treated with the highest rate of imazosulfuron (1680 $\mathrm{g}$ a.i./ha) had $<10 \%$ visual injury, leaf number, height, and tuber weight reduction compared with the nontreated control. Both caladium cultivars exhibited greater susceptibility to flazasulfuron, foramsulfuron, and mesosulfuron as compared with imazosulfuron. The labelrecommended rate of flazasulfuron $(52 \mathrm{~g}$ a.i./ha), foramsulfuron $(29 \mathrm{~g}$ a.i./ha), and mesosulfuron (15 $\mathrm{g}$ a.i./ha) reduced 'Florida Cardinal' height $35 \%, 27 \%$, and $35 \%$, respectively, and reduced 'Florida Fantasy' height $43 \%, 31 \%$, and $21 \%$ compared with the nontreated plants, respectively. Caladium tuber weight exhibited a differential cultivar response to the evaluated $S U$ herbicides, except imazosulfuron. The highest rate of flazasulfuron $\left(420 \mathrm{~g} \cdot \mathrm{ha}^{-1}\right)$, foramsulfuron $\left(232 \mathrm{~g} \cdot \mathrm{ha}^{-1}\right)$, and mesosulfuron $\left(120 \mathrm{~g} \cdot \mathrm{ha}^{-1}\right)$ reduced 'Florida Cardinal' tuber weight $50 \%, 65 \%$, and $58 \%$ compared with the nontreated control, respectively, whereas these treatments reduced 'Florida Fantasy' tuber weight $<\mathbf{2 5 \%}$. The mesosulfuron rate required for $\mathbf{2 0} \%$ tuber weight reduction $\left(T_{20}\right)$ in 'Florida Cardinal' was $2 \mathrm{~g} \cdot \mathrm{ha}^{-1}$, but the $\mathbf{T}_{20}$ value was $28 \mathrm{~g} \cdot \mathrm{ha}^{-1}$ for 'Florida Fantasy'. We concluded that the caladium cultivars Florida Cardinal and Florida Fantasy are highly tolerant to the POST applications of imazosulfuron, whereas these caladium cultivars are more susceptible to flazasulfuron, foramsulfuron, and mesosulfuron.
\end{abstract}

Caladium (C. bicolor spp.), a member of the plant family Araceae (aroid), is valued for its long-lasting colorful foliage. Caladium is widely planted in gardens and landscapes and used as ornamental plants. After years of plant breeding, caladium cultivars and hybrids are available in a wide range of leaf colors, shapes, sizes, and plant heights (Bell et al., 1998; Cai et al., 2015; Cao and Deng, 2017; Cao et al., 2014, 2016a, 2016b, 2017; Deng, 2012; Deng et al., 2016; Miranda and Harbaugh, 2003). There are two broad caladium categories, including fancy-leaved (wide leaves) and strap-leaved (narrow leaves) cultivars (Deng and Harbaugh, 2006; Deng et al., 2008). White fancyleaved caladium cultivars are popular because they can create a striking contrast with surrounding flowers, grass, tress, or shrubs (Deng and Harbaugh, 2006). Most of the

\footnotetext{
Received for publication 6 Feb. 2018. Accepted for publication 19 Apr. 2018.

We would like to thank Mike Sweat, Nicole Billera, Hector Torres, and Radhika Rijal for their technical assistance with this research.

Tubers were provided by Happiness Farms, Inc. and Research funding was provided by Florida caladium growers.

${ }^{1}$ Corresponding author. E-mail: nsboyd@ufl.edu.
}

control may result if applications are inappropriately timed. The use of POST herbicides that are effective on weeds would benefit caladium growers by increasing herbicide options beyond fumigation and PRE herbicides. Unfortunately, there are no registered POST herbicides to control emerged weeds in caladium. Identification of POST herbicides that are safe to caladium yet effectively control weeds is a key obstacle to successful production of caladium tubers. Therefore, research is needed to identify herbicides that can be POST applied on caladium.

Flazasulfuron, foramsulfuron, imazosulfuron, and mesosulfuron are in the SU herbicide family. The SU herbicides inhibit acetolactate synthase (E.C. 4.1.3.18), also known as acetohydroxyacid synthase, a key enzyme in the biosynthesis of the branchedchain amino acids isoleucine, leucine, and valine. Foramsulfuron provides POST control of doveweed [Murdannia nudiflora (L.) Brenan], henbit (Lamium amplexicaule L.), and goosegrass [Eleusine indica (L.) Gaertn.] (Revolver ${ }^{\circledR}$ Herbicide; Bayer CropScience, Research Triangle Park, NC); flazasulfuron provides POST control of Carolina geranium (Geranium carolinianum L.), black medic (Medicago lupulina L.), sedges (Cyperus spp.), and southern crabgrass [Digitaria ciliaris (Retz.) Koel.] (Katana ${ }^{\circledR}$ Turf Herbicide; PBI/Gordon Corporation, Kansas City, Missouri); imazosulfuron provides PRE control of large crabgrass [Digitaria sanguinalis (L.) Scop.] and black nightshade (Solanum nigrum L.), and POST control of common purslane (Portulaca oleracea L.), hairy galinsoga (Galinsoga quadriradiata Cav.), and morning glory species (Ipomoea spp.) (League ${ }^{\circledR}$ Herbicide; Valent U.S.A. Corporation, Walnut Creek, CA; Webster and Masson, 2001); and mesosulfuron provides POST control of many broadleaf weeds, including wild radish (Raphanus raphanistrum L.) (Osprey ${ }^{\circledR}$ Herbicide; Bayer CropScience). The aforementioned weed species are common and problematic in field-grown caladium. However, little is known about caladium tolerance to foramsulfuron, flazasulfuron, imazosulfuron, and mesosulfuron. Therefore, the objective of this research was to determine caladium tolerance to these $\mathrm{SU}$ herbicides.

\section{Materials and Methods} caladium growers rely on hand weeding.

Several preemergence (PRE) herbicides have been successfully evaluated for use in field-grown caladium. Gilreath et al. (1985) evaluated 12 PRE herbicides and found that oryzalin consistently provided acceptable weed control with little or no caladium injury at rates ranging from $1680 \mathrm{~g}$ a.i./ha on mineral soils to $1680-3360 \mathrm{~g}$ a.i./ha on muck soils. Gilreath et al. (1994) reported that flumetralin, metolachlor, and a combination of isoxaben and oryzalin provided effective weed control without causing adverse effect on caladium. However, the PRE herbicides do not control emerged weeds, and poor weed
Experiment description. Two separate greenhouse experiments were conducted from June to Oct. 2016 and June to Oct. 2017 at the Gulf Coast Research and Education Center in Balm, FL (lat. $27.75^{\circ} \mathrm{N}$, long. $82.26^{\circ} \mathrm{W}$ ), to evaluate six rates of flazasulfuron, foramsulfuron, imazosulfuron, and mesosulfuron on caladium cultivars Florida Cardinal and Florida Fantasy. 'Florida Cardinal' is a fancy red-leaved cultivar, whereas 'Florida Fantasy' is a fancy white-leaved cultivar.

Caladium tubers were collected from a commercial caladium field in Highlands 

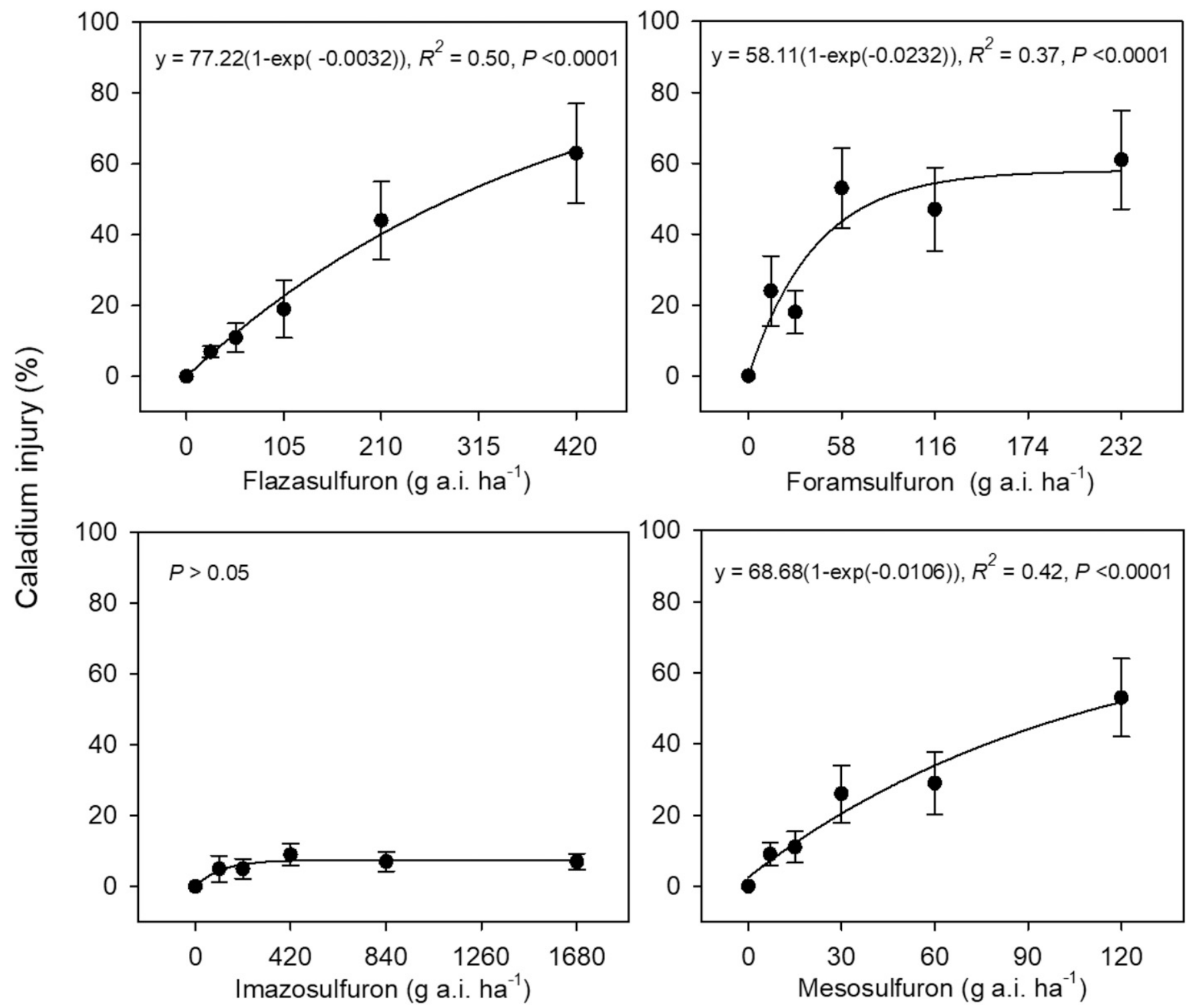

Fig. 1. Percent caladium 'Florida Cardinal' injury at 8 weeks after applications of flazasulfuron, foramsulfuron, imazosulfuron, and mesosulfuron in two combined greenhouse experiments in Balm, FL. Results were pooled over experimental runs. Means represent the average of eight observations. Vertical bars represent SES $(n=8)$. $P$ value above 0.05 did not achieve a significant nonlinear relationship.

County, FL (lat. $27.34^{\circ} \mathrm{N}$, long. $81.34^{\circ} \mathrm{W}$ ). Uniform caladium tubers $(4-5 \mathrm{~cm}$ in diameter) were selected and planted one tuber per pot with $225-\mathrm{cm}^{2}$ surface areas and $16.5-\mathrm{cm}$ depths in a greenhouse set for $28 / 16^{\circ} \mathrm{C}$ (day/ night). The soil was commercial potting soil including $30 \%$ canadian peat, $20 \%$ cypress dust, $20 \%$ pine bark, $20 \%$ bark, and $10 \%$ perlite at $\mathrm{pH}$ 5.5-6.5. Tubers were planted on 25 June 2016 and 30 June 2017. Six grams of 14-9-15 (N-P-K) Plantacote Pluss (XCalibur Plant Health Company, Summerville, SC) was mixed into the upper $5 \mathrm{~cm}$ of the soil at 2 weeks after planting to promote plant growth. The plants were irrigated as needed to prevent moisture stress. The plant height and leaf number were $21( \pm 1.2 \mathrm{SE}) \mathrm{cm}$ and $2.9( \pm 0.7 \mathrm{SE})$ leaves/plant for 'Florida Cardinal', respectively, and were $15( \pm 1.2 \mathrm{SE})$ $\mathrm{cm}$ and $4( \pm 0.4 \mathrm{SE})$ leaves/plant for 'Florida Fantasy', respectively, when the herbicides were applied.
Herbicide rates were based on $0,0.5 \times, 1 \times$, $2 \times, 4 \times$, and $8 \times$ the recommended rate where the $1 \times$ rate for each herbicide was the rate registered for use in the labeled crop species. Flazasulfuron was applied at 26, 53, 105, 210 , or $420 \mathrm{~g}$ a.i./ha; foramsulfuron was applied at $14,29,58,116$, or $232 \mathrm{~g}$ a.i./ha; imazosulfuron was applied at 105, 210, 420, 840 , or $1680 \mathrm{~g}$ a.i./ha; and mesosulfuron was applied at $7,15,30,60$, or $120 \mathrm{~g}$ a.i./ha. All herbicides were applied using a $\mathrm{CO}_{2}$-pressured sprayer at $187 \mathrm{~L} \cdot \mathrm{ha}^{-1}$ spray volume with a single 8002E flat-fan nozzle (Teejet, Spraying Systems Co., Wheaton, IL). A nontreated control was included in each replication. A nonionic surfactant at $0.2 \%$ by volume was included in the herbicide treatments. The plants were returned to the greenhouse $1 \mathrm{~h}$ after treatment and drip irrigation was withheld for $24 \mathrm{~h}$.

Data collection. Caladium injury was visually evaluated on a percent scale, where 0 equaled no injury from the nontreated control and 100 equaled complete desiccation. Visual evaluation of caladium injury was based on chlorosis, necrosis, and shoot stunting. Evaluations for caladium visual injury were made 2,4 , and 8 WAT of herbicide. Results from 8 WAT are presented because of similar trends among treatments at 2, 4, and 8 WAT. Caladium heights were measured using a rule and leaf numbers were counted on the day of herbicide treatment and 8 WAT. Caladium tubers were harvested at 8 WAT. Soil adhering to the tubers was flushed off with tap water and fresh weight was determined once roots were removed and the tuber was air-dried.

Experimental design and statistical analysis. The experiments were set up as a complete randomized design with four replications. A nontreated control was included in each block. Data were subjected to analysis of variance at the $0.05 P$ level in SAS (version 9.4; SAS Institute, Cary, NC) using 

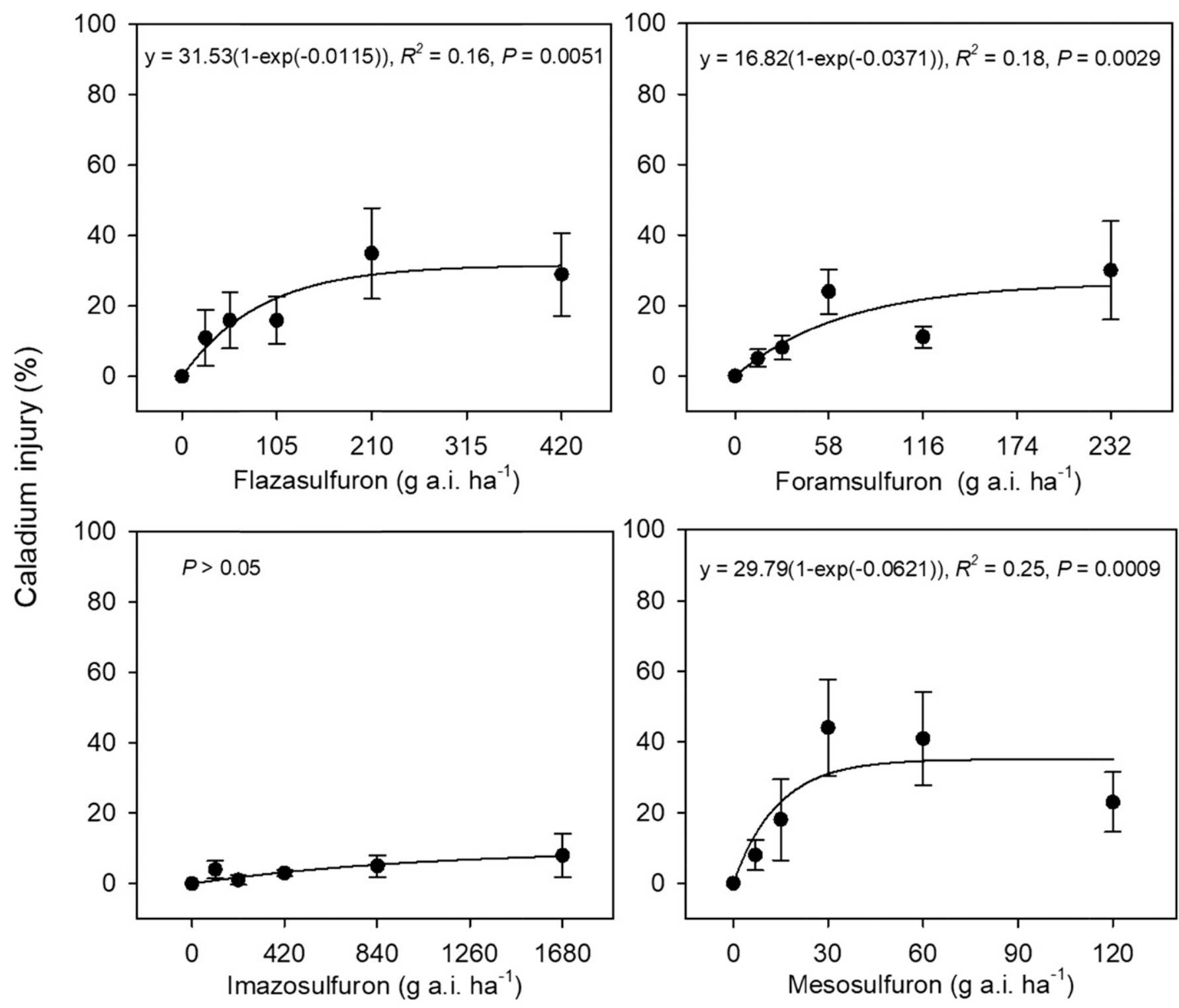

Fig. 2. Percent caladium 'Florida Fantasy' injury at 8 weeks after applications of flazasulfuron, foramsulfuron, imazosulfuron, and mesosulfuron in two combined greenhouse experiments in Balm, FL. Results were pooled over experimental runs. Means represent the average of eight observations. Vertical bars represent SES $(n=8) . P$ value above 0.05 did not achieve a significant nonlinear relationship.

the PROC GLM procedure. Data were pooled over experimental runs because experiment by treatment interaction was not detected. Data were regressed with the following twoparameter growth function equation:

$$
y=\beta_{0}\left\{1-\left[\exp \left(-\beta_{1} x\right)\right]\right\},
$$

where $y$ is plant response, $\beta_{0}$ is the asymptote, $\beta_{1}$ is the slope estimate, and $x$ is the herbicide rate. SE values and $95 \%$ confidence intervals were determined across all replications with SigmaPlot (Systat Software, Inc., San Jose, CA). Effective herbicide rate required to cause $20 \%$ caladium visual injury $\left(\mathrm{I}_{20}\right)$, height $\left(\mathrm{H}_{20}\right)$, leaf number $\left(\mathrm{L}_{20}\right)$, and tuber weight $\left(\mathrm{T}_{20}\right)$ reduction following herbicide applications were determined from the regression curves. These values were determined from fitted regressions because $20 \%$ visual injury, height, leaf number, or tuber weight reduction may be considered unacceptable for caladium growth and tuber production. For data presentation, treatment means are presented with sEs in figures.

\section{Results and Discussion}

Visual injury. The herbicidal symptoms included cessation of plant growth followed by chlorosis or purpling of leaf veins and necrosis. The evaluated imazosulfuron rates ranging from 105 to $1680 \mathrm{~g} \cdot \mathrm{ha}^{-1}$ caused minimal visual injury for both cultivars (Figs. 1 and 2). At 8 WAT, 'Florida Cardinal' injury ranged $4 \%$ to $9 \%$, whereas 'Florida Fantasy' injury ranged $3 \%$ to $8 \%$ from the imazosulfuron treatments. There was no clear relationship between visual injury and imazosulfuron rate, and the $\mathrm{I}_{20}$ was not achieved (Table 2). These results indicate that both cultivars are highly tolerant to imazosulfuron.

Caladium exhibited substantially greater susceptibility to flazasulfuron, foramsulfuron, and mesosulfuron than imazosulfuron. The recommended rates of flazasulfuron $\left(53 \mathrm{~g} \cdot \mathrm{ha}^{-1}\right)$, foramsulfuron $\left(29 \mathrm{~g} \cdot \mathrm{ha}^{-1}\right)$, and mesosulfuron (15 $\mathrm{g} \cdot \mathrm{ha}^{-1}$ ) injured 'Florida Cardinal' $20 \%, 19 \%$, and $12 \%$, respectively, and injured 'Florida Fantasy' $18 \%, 9 \%$, and $20 \%$, respectively. In comparison, the label-recommended rate of imazosulfuron $\left(210 \mathrm{~g} \cdot \mathrm{ha}^{-1}\right)$ caused $<5 \%$ visual injury. Based on $\mathrm{I}_{20}$ values, 87,17 , and $28 \mathrm{~g} \cdot \mathrm{ha}^{-1}$ of flazasulfuron, foramsulfuron, and mesosulfuron were required to cause $20 \%$ 'Florida Cardinal' visual injury, respectively, and 80, 90, and $11 \mathrm{~g} \cdot \mathrm{ha}^{-1}$ were required to cause 20\% 'Florida Fantasy' visual injury, respectively (Table 1).

Caladium cultivars exhibited a differential injury response to the SU herbicides evaluated with the exception of imazosulfuron. At the highest rates, flazasulfuron, foramsulfuron, and mesosulfuron at 420, 232, and $120 \mathrm{~g} \cdot \mathrm{ha}^{-1}$ injured 'Florida Cardinal' 63\%, $61 \%$, and $53 \%$, respectively, whereas these herbicide treatments injured 'Florida Fantasy' 


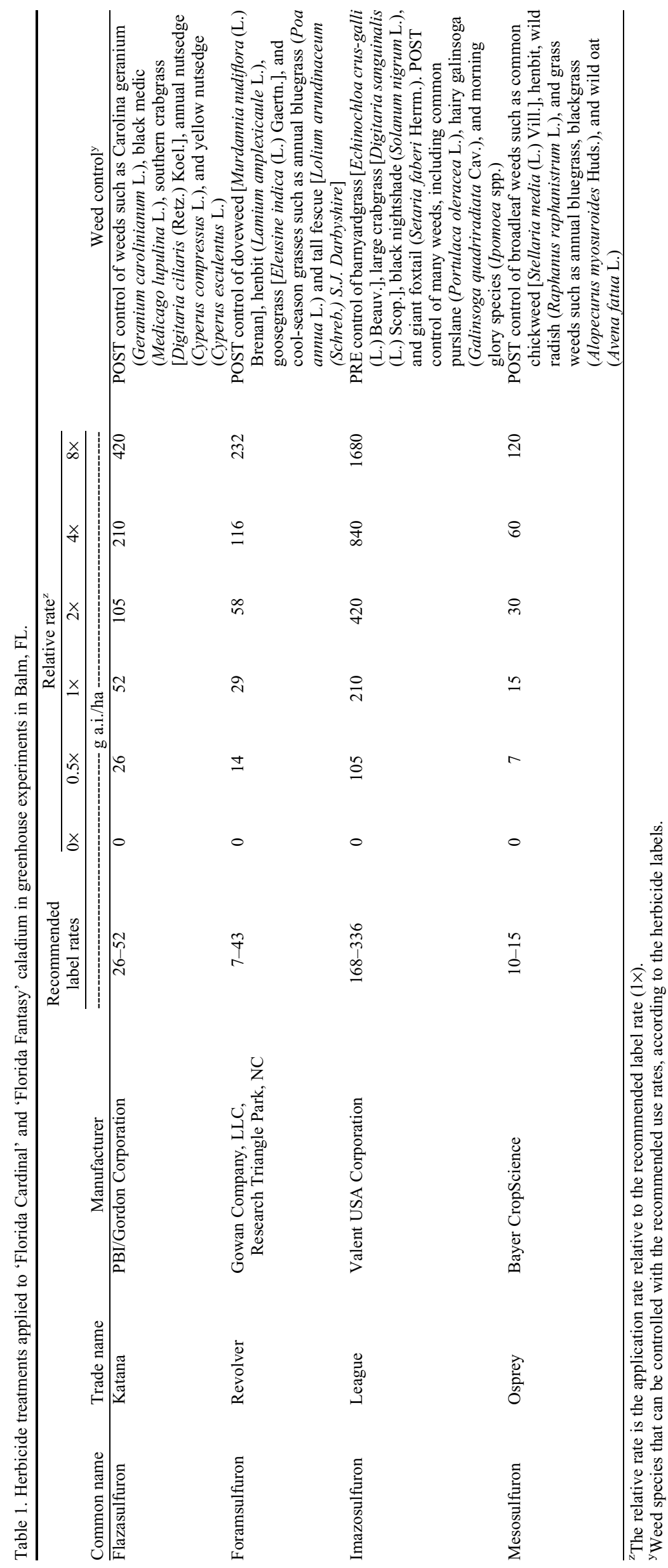

$28 \%, 30 \%$, and $23 \%$, respectively. Moreover, the $\mathrm{I}_{20}$ value for 'Florida Cardinal' was $\approx 5.3$ fold less than 'Florida Fantasy' from the foramsulfuron treatments. These findings suggested that 'Florida Cardinal' is more susceptible to flazasulfuron, foramsulfuron, and mesosulfuron than 'Florida Fantasy'. We speculate that the variable tolerance of caladium cultivars to the SU herbicides is due to differential cuticular penetration, herbicide translocation, or metabolism. In previous research, Burton et al. (1994) reported that differential tolerance of corn (Zea mays L.) varieties to primisulfuron and nicosulfuron is associated with herbicide metabolism.

Plant height. For both cultivars, the evaluated imazosulfuron rates did not significantly reduce caladium height from the nontreated control (Figs. 3 and 4). In fact, 'Florida Cardinal' and 'Florida Fantasy' treated with the imazosulfuron rates ranging from 105 to $840 \mathrm{~g} \cdot \mathrm{ha}^{-1}$ were taller than the nontreated plants, although they were not statistically different compared with the nontreated plants $(P>0.05)$. For both cultivars, the $\mathrm{H}_{20}$ was not achieved for imazosulfuron because the highest rate of imazosulfuron at $1680 \mathrm{~g} \cdot \mathrm{ha}^{-1}$ reduced caladium height $<5 \%$ from the nontreated plants. In comparison, the highest rate of flazasulfuron, foramsulfuron, and mesosulfuron reduced 'Florida Cardinal' height $68 \%, 60 \%$, and $42 \%$, respectively, and reduced 'Florida Fantasy' height $42 \%, 56 \%$ and $41 \%$ compared with the nontreated control, respectively. The $\mathrm{H}_{20}$ for 'Florida Cardinal' treated with flazasulfuron, foramsulfuron, and mesosulfuron was 64,16 , and $5 \mathrm{~g} \cdot \mathrm{ha}^{-1}$, respectively, and the $\mathrm{H}_{20}$ for 'Florida Fantasy' was 11, 20, and $6 \mathrm{~g} \cdot \mathrm{ha}^{-1}$, respectively (Table 2 ).

Leaf number. Both cultivars treated with the highest rate of imazosulfuron did not significantly reduce caladium leaves compared with the nontreated control, and, thus, the $\mathrm{L}_{20}$ was not obtained from the regression curves (Figs. 5 and 6). In comparison, the label-recommended rates of foramsulfuron (29 g.ha $\mathrm{g}^{-1}$ ) and mesosulfuron (15 g.ha ${ }^{-1}$ ) reduced 'Florida Cardinal' leaves $38 \%$ and $30 \%$, respectively, and reduced 'Florida Fantasy' leaves $30 \%$ and $53 \%$ compared with the nontreated control, respectively. The highest rate of flazasulfuron, foramsulfuron, and mesosulfuron reduced 'Florida Cardinal' leaves $50 \%, 64 \%$, and $55 \%$, respectively, and reduced 'Florida Fantasy' leaves $41 \%$, $20 \%$, and $74 \%$ compared with the nontreated control, respectively. The $\mathrm{L}_{20}$ values were comparable between cultivars. The $\mathrm{L}_{20}$ for 'Florida Cardinal' treated with flazasulfuron, foramsulfuron, and mesosulfuron was 90,15 , and $7 \mathrm{~g} \cdot \mathrm{ha}^{-1}$, respectively, and the $\mathrm{L}_{20}$ for 'Florida Fantasy' was 90, 22, and 5 g.ha ${ }^{-1}$, respectively.

Herbicides are typically applied during the first several months of caladium tuber production before the canopy closure of the space between rows (Gilreath et al., 1994). POST applications of flazasulfuron, foramsulfuron, and mesosulfuron may reduce the foliage production and delay the closure of 

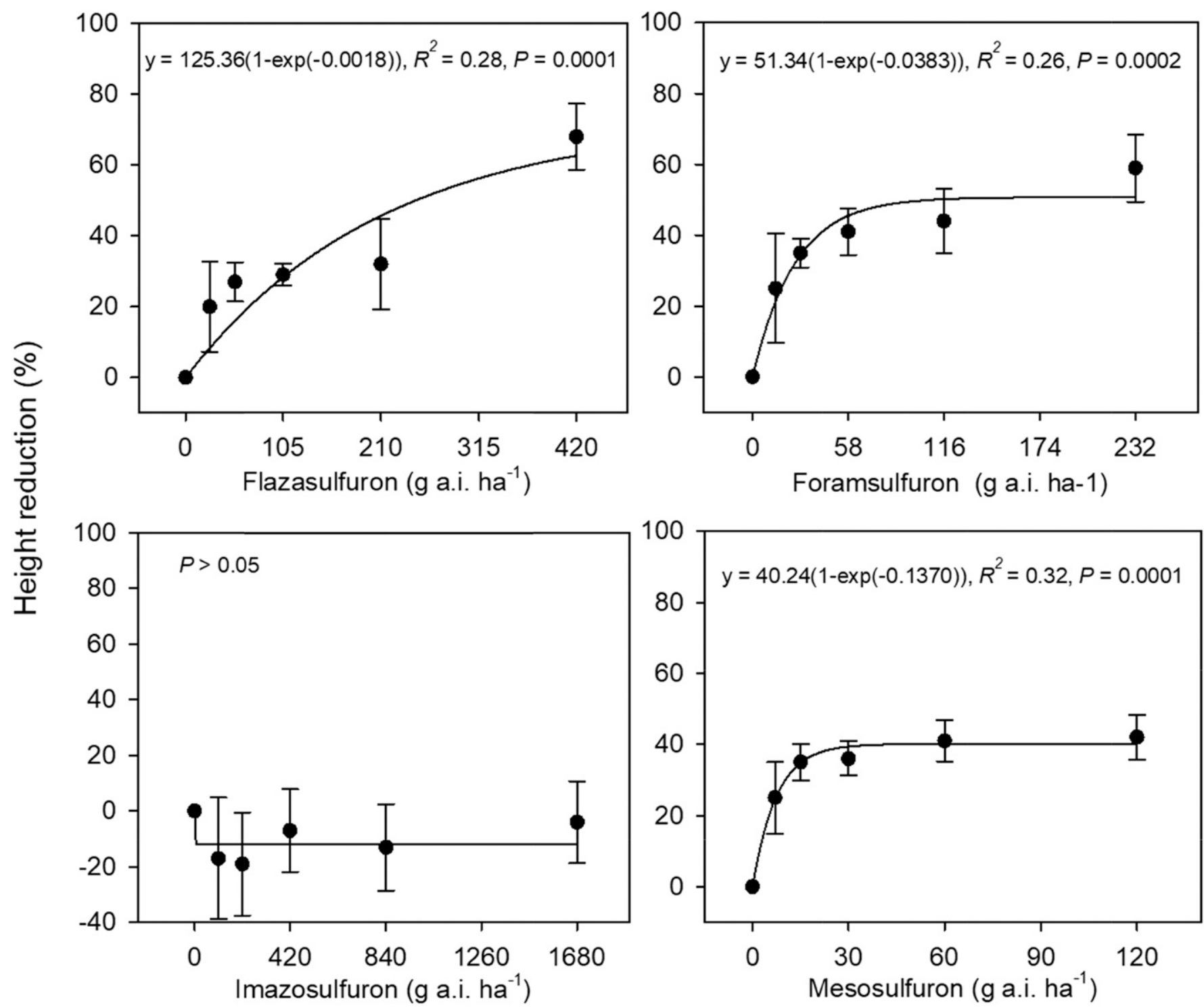

Fig. 3. Percent caladium 'Florida Cardinal' height reduction at 8 weeks after applications of flazasulfuron, foramsulfuron, imazosulfuron, and mesosulfuron in two combined greenhouse experiments in Balm, FL. Results were pooled over experimental runs. Means represent the average of eight observations. Vertical bars represent SES $(n=8)$. $P$ value above 0.05 did not achieve a significant nonlinear relationship. Caladium height $( \pm \mathrm{SE})$ of nontreated control measured $21( \pm 1.2)$ $\mathrm{cm}$ and $39( \pm 2.8) \mathrm{cm}$ on the day of herbicide treatment and at 8 weeks after herbicide applications, respectively.

canopy. This would reduce the caladium competitiveness against weeds due to inadequately covered soil.

Tuber weight. Similar to the responses of caladium height and leaves, 'Florida Cardinal' and 'Florida Fantasy' treated with the lowest rate of imazosulfuron (105 g.ha $\left.{ }^{-1}\right)$ tended to produce more tubers compared with the nontreated control. For both cultivars, the highest rate of imazosulfuorn (1680 $\mathrm{g} \cdot \mathrm{ha}^{-1}$ ) reduced tuber weight $<10 \%$ compared with the nontreated control and, thus, the $\mathrm{T}_{20}$ was not determined from the regression curves (Table 2; Figs. 7 and 8). By contrast, both caladium cultivars exhibited greater susceptibility to other SU herbicides. Tuber weight generally decreased as the rates of flazasulfuron, foramsulfuron, and mesosulfuron increased.

It is worth noting that the lowest rate of foramsulfuron $\left(14 \mathrm{~g} \cdot \mathrm{ha}^{-1}\right)$ and mesosulfuron (7 g.ha ${ }^{-1}$ ) reduced 'Florida Cardinal' tuber weight $50 \%$ and $40 \%$, respectively, whereas these treatments reduced 'Florida Fantasy' tuber weight $<10 \%$ compared with the nontreated plants. Moreover, the highest rate of flazasulfuron, foramsulfuron, and mesosulfuron reduced 'Florida Cardinal' tuber weight $50 \%, 65 \%$, and $58 \%$ compared with the nontreated plants, respectively. By contrast, these treatments reduced 'Florida Fantasy' tuber weight $<25 \%$. The tuber weight for 'Florida Cardinal' treated with imazosulfuron and 'Florida Fantasy' treated with flazasulfuron, foramsulfuron, and imazosulfuron did not exhibit a clear regression relationship and, thus, the $T_{20}$ values were not established. The $\mathrm{T}_{20}$ for 'Florida Cardinal' treated with mesosulfuron was $\approx 14$-fold less than 'Florida Fantasy'. Collectively, these findings suggest that the tuber growth of 'Florida Cardinal' is more susceptible to flazasulfuron, foramsulfuron, and mesosulfuron as compared with 'Florida Fantasy'.
Further research is warranted to investigate the physiological basis for SU herbicide tolerance and selectivity among caladium cultivars.

Differential cultivar responses to SU herbicides have also been reported for bahiagrass (Paspalum notatum Fluegge), corn ( $Z$. mays L.), and wheat (Bunnell et al., 2003; Dastgheib et al., 1994; O'Sullivan et al., 1998; Pornprom and Pyon, 1999). Although 'Florida Cardinal' and 'Florida Fantasy' are highly tolerant to imazosulfuron, growers may need to evaluate, on a small scale, the potential for injury on cultivars grown in their operation. Considerable variability may exist for herbicide tolerance between cultivars and further research is needed. Interestingly, both cultivars treated with the lowest rate of imazosulfuron at $105 \mathrm{~g} \cdot \mathrm{ha}^{-1}$ tended to be taller and produced more leaves and tubers, suggesting that low rate of imazosulfuron may stimulate caladium growth. This finding, 

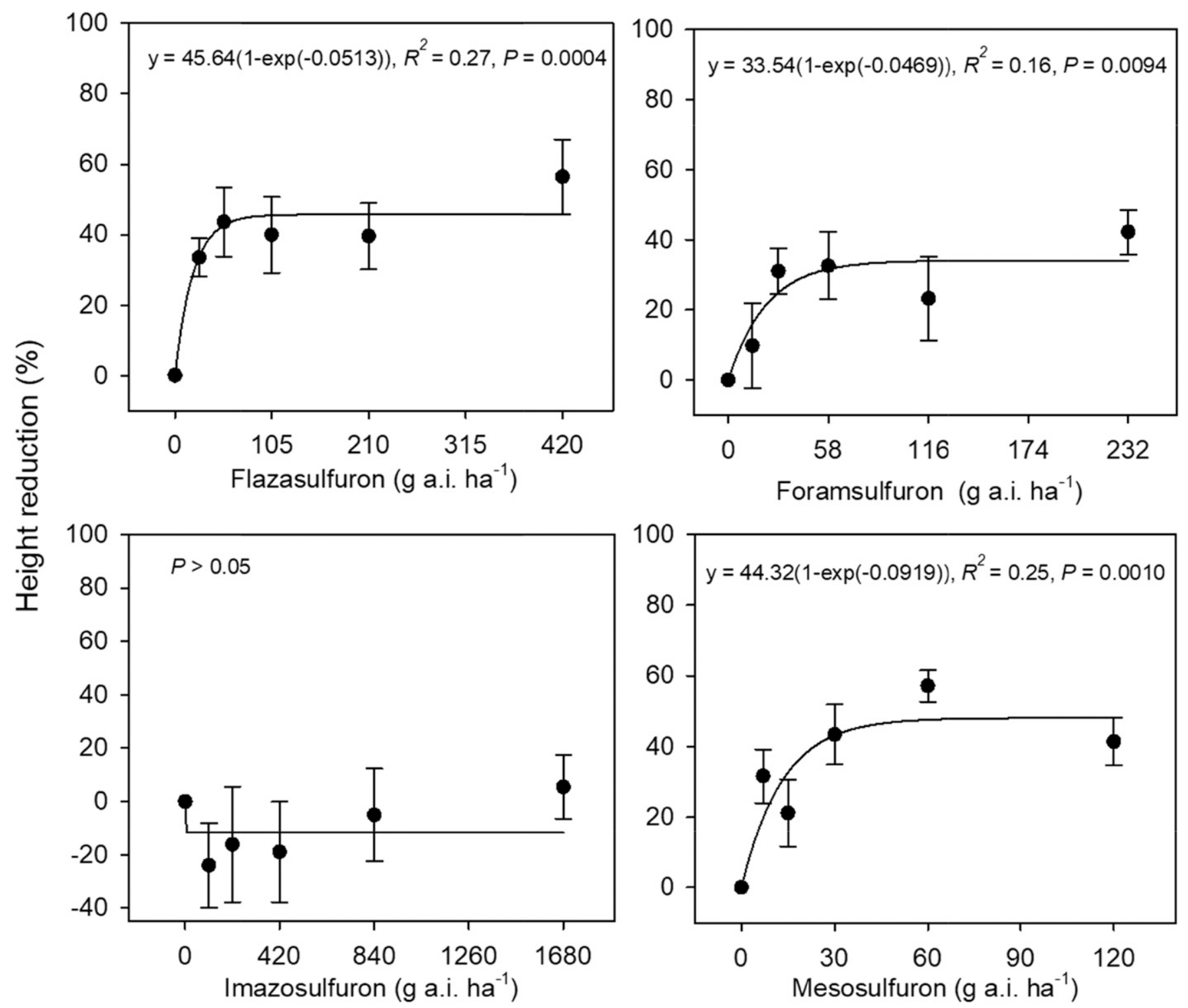

Fig. 4. Percent caladium 'Florida Fantasy' height reductions after flazasulfuron, foramsulfuron, imazosulfuron, and mesosulfuron applications in two combined greenhouse experiments in Balm, FL. Results were pooled over experimental runs. Means represent the average of eight observations. Vertical bars represent SES $(n=8)$. $P$ value above 0.05 did not achieve a significant nonlinear relationship. Caladium height $( \pm \mathrm{SE})$ of nontreated control measured $15( \pm 1.2) \mathrm{cm}$ and 30 $( \pm 2.0) \mathrm{cm}$ on the day of herbicide treatment and at 8 weeks after herbicide applications, respectively.

Table 2. Effective herbicide rate required to cause $20 \%$ caladium visual injury $\left(\mathrm{I}_{20}\right)$, height $\left(\mathrm{H}_{20}\right)$, leaf number $\left(\mathrm{L}_{20}\right)$, and tuber weight reduction $\left(\mathrm{T}_{20}\right)$ following flazasulfuron, foramsulfuron, imazosulfuron, and mesosulfuron applications in two combined greenhouse experiments, Balm, FL. ${ }^{2}$

\begin{tabular}{|c|c|c|c|c|c|c|c|c|c|}
\hline \multirow[b]{3}{*}{ Cultivar } & \multirow[b]{3}{*}{ Herbicide } & \multicolumn{2}{|r|}{ Injury } & \multicolumn{2}{|r|}{$\mathrm{Ht}$} & \multicolumn{2}{|r|}{ Leaf no. } & \multicolumn{2}{|r|}{ Tuber wt } \\
\hline & & $\mathrm{I}_{20}$ & $95 \%$ CI for $\mathrm{I}_{20}$ & $\overline{\mathrm{H}_{20}}$ & $95 \% \mathrm{CI}$ for $\mathrm{H}_{20}$ & $\mathrm{~L}_{20}$ & $95 \% \mathrm{CI}$ for $\mathrm{L}_{20}$ & $\mathrm{~T}_{20}$ & $95 \%$ CI for $\mathrm{L}_{20}$ \\
\hline & & \multicolumn{8}{|c|}{ - } \\
\hline \multirow[t]{3}{*}{ Florida Cardinal } & Flazasulfuron & 87 & $57-117$ & 64 & $33-95$ & 90 & $33-147$ & 43 & $30-56$ \\
\hline & Imazosulfuron & $\mathrm{NF}$ & NA & $\mathrm{NF}$ & NA & $\mathrm{NF}$ & NA & $\mathrm{NF}$ & NA \\
\hline & Mesosulfuron & 28 & $17-39$ & 5 & $4-6$ & 7 & $5-9$ & 2 & $1.5-2.5$ \\
\hline \multirow[t]{2}{*}{ Florida Fantasy } & Flazasulfuron & 80 & $34-126$ & 11 & $7-15$ & 90 & $32-148$ & NF & NA \\
\hline & Foramsulfuron & 90 & $35-145$ & 20 & $8-32$ & $\mathrm{NF}$ & NA & NF & NA \\
\hline
\end{tabular}

${ }^{\mathrm{z}}$ Data were regressed with the following equation, $y=\beta_{0}\left\{1-\left[\exp \left(-\beta_{1} x\right)\right]\right\}$, where $y$ is percent control, $\beta_{0}$ is the asymptote, $\beta_{1}$ is the slope estimate, and $x$ is herbicide rate.

$\mathrm{CI}=$ confidence interval; $\mathrm{NA}=$ not applicable; $\mathrm{NF}=$ not found

however, is preliminary and does not present conclusive evidence but warrants further investigation with larger samples. The stimulation

HortScience Vol. 53(6) June 2018 of plant growth at sublethal herbicide doses is a common phenomenon and has been widely documented (Cedergreen, 2008; Gowda and Prakash, 1998; Velini et al., 2008; Wiedman and Appleby, 1972). For example, Velini et al. (2008) reported that low 

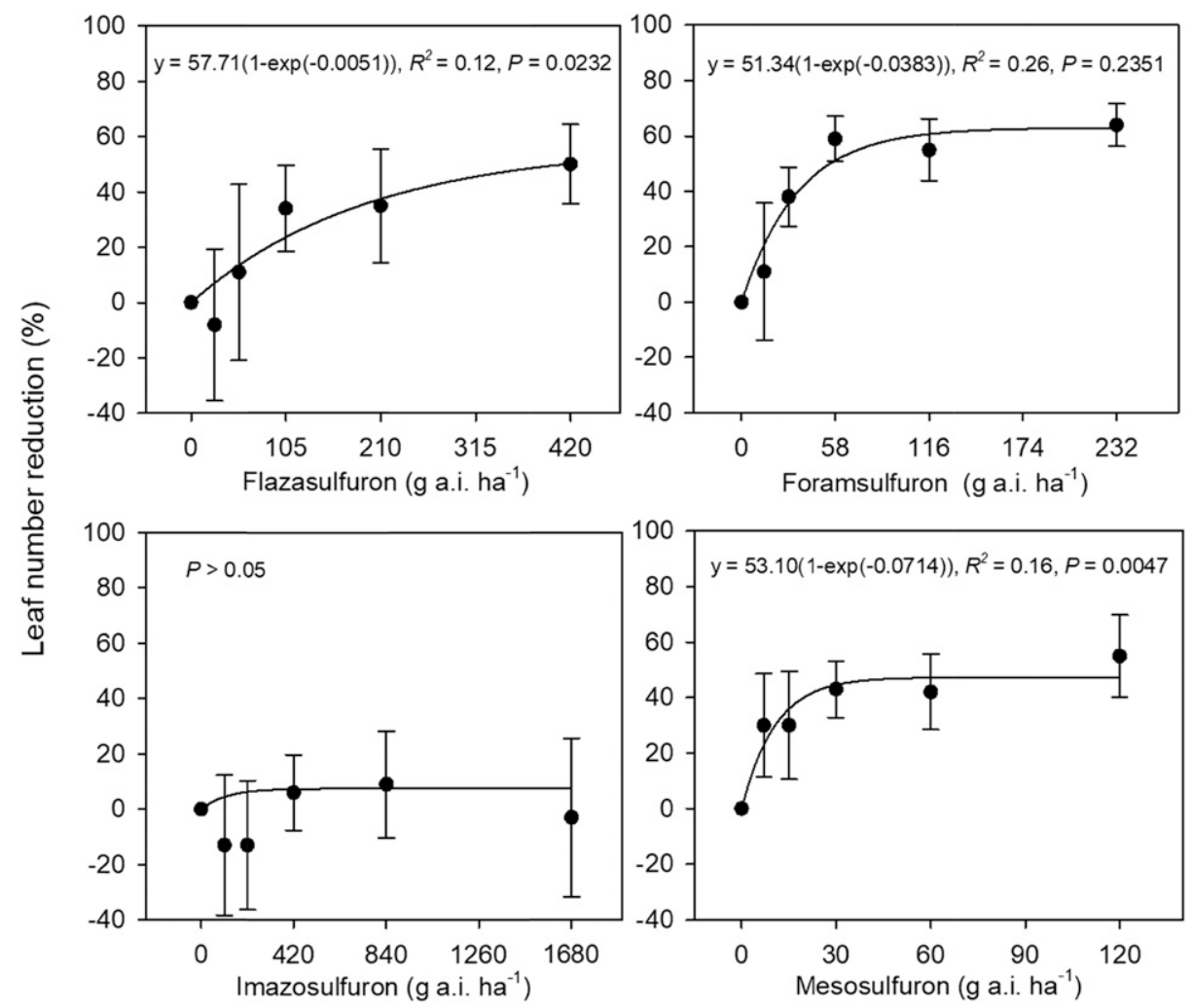

Fig. 5. Percent caladium 'Florida Cardinal' leaf number reduction at 8 weeks after applications of flazasulfuron, foramsulfuron, imazosulfuron, and mesosulfuron in two combined greenhouse experiments in Balm, FL. Results were pooled over experimental runs. Means represent the average of eight observations. Vertical bars represent SEs $(n=8)$. $P$ value above 0.05 did not achieve a significant nonlinear relationship. Caladium leaf number ( \pm SE) of nontreated control measured $2.9( \pm 0.7)$ leaves/plant and $17.4( \pm 2.1)$ leaves/plant on the day of herbicide treatment and at 8 weeks after herbicide applications, respectively.
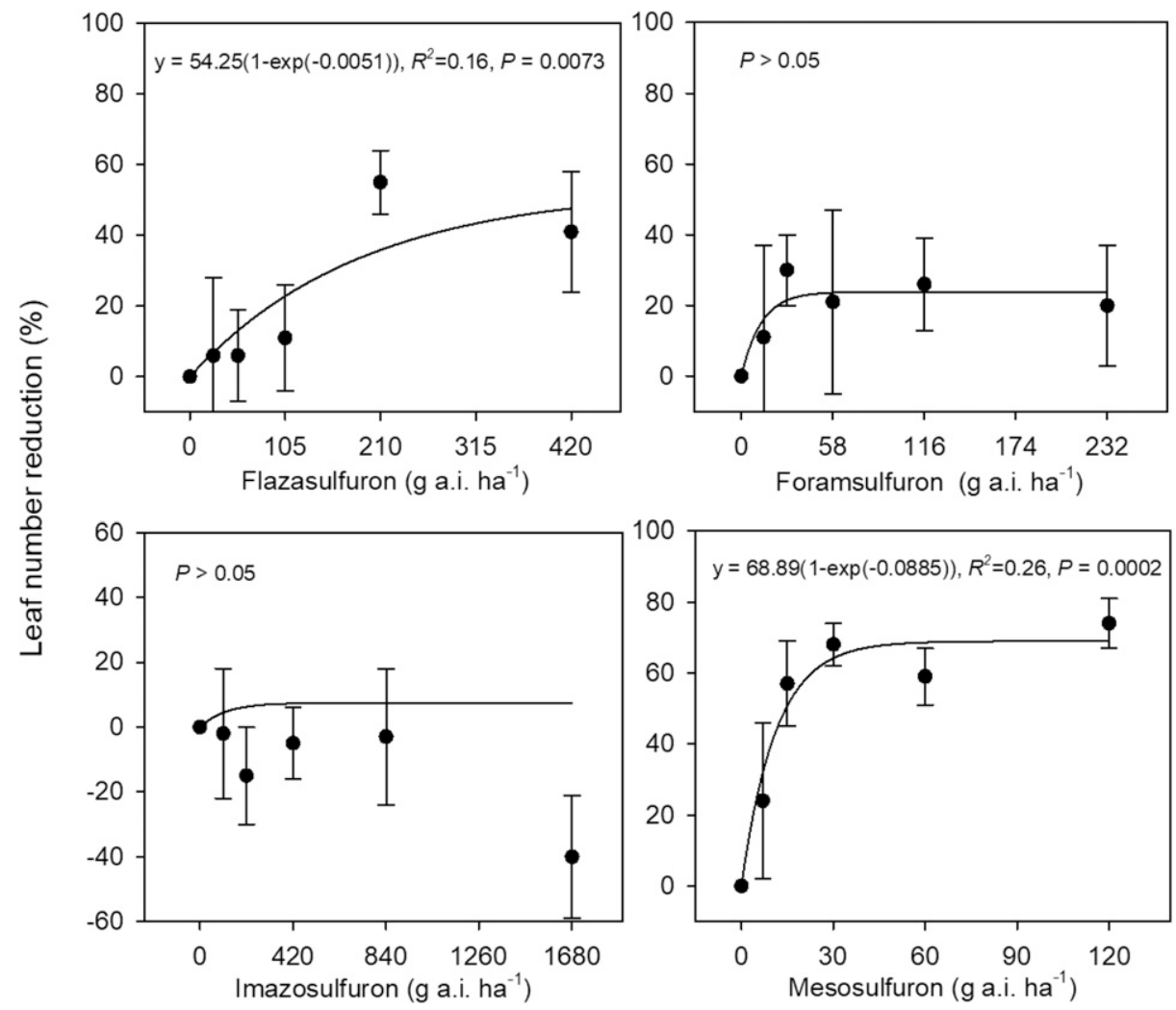

Fig. 6. Percent caladium 'Florida Fantasy' leaf number reduction at 8 weeks after applications of flazasulfuron, foramsulfuron, imazosulfuron, and mesosulfuron in two combined greenhouse experiments in Balm, FL. Results were pooled over experimental runs. Means represent the average of eight observations. Vertical bars represent SEs $(n=8)$. $P$ value above 0.05 did not achieve a significant nonlinear relationship. Caladium leaf number $( \pm \mathrm{SE})$ of nontreated control measured $4.0( \pm 0.4)$ leaves/plant and $8.9( \pm 1.1)$ leaves/plant on the day of herbicide treatment and at 8 weeks after herbicide applications, respectively. 

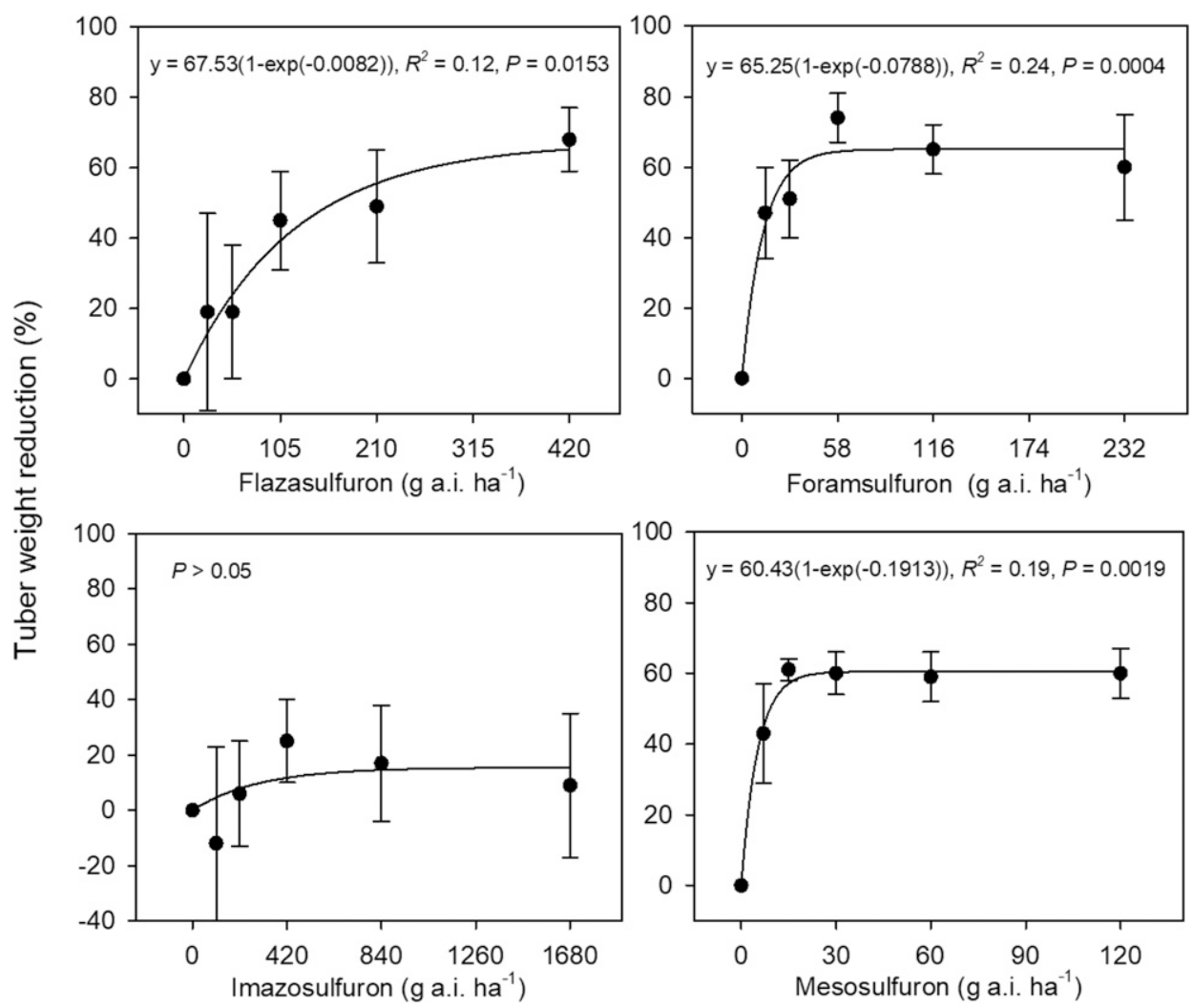

Fig. 7. Percent caladium 'Florida Cardinal' tuber weight reduction at 8 weeks after applications of flazasulfuron, foramsulfuron, imazosulfuron, and mesosulfuron in two combined greenhouse experiments in Balm, FL. Results were pooled over experimental runs. Means represent the average of eight observations. Vertical bars represent SES $(n=8)$. $P$ value above 0.05 did not achieve a significant nonlinear relationship. Caladium tuber weight $( \pm \mathrm{SE})$ of nontreated control measured $78.8( \pm 11.6) \mathrm{g} /$ plant at 8 weeks after herbicide applications.
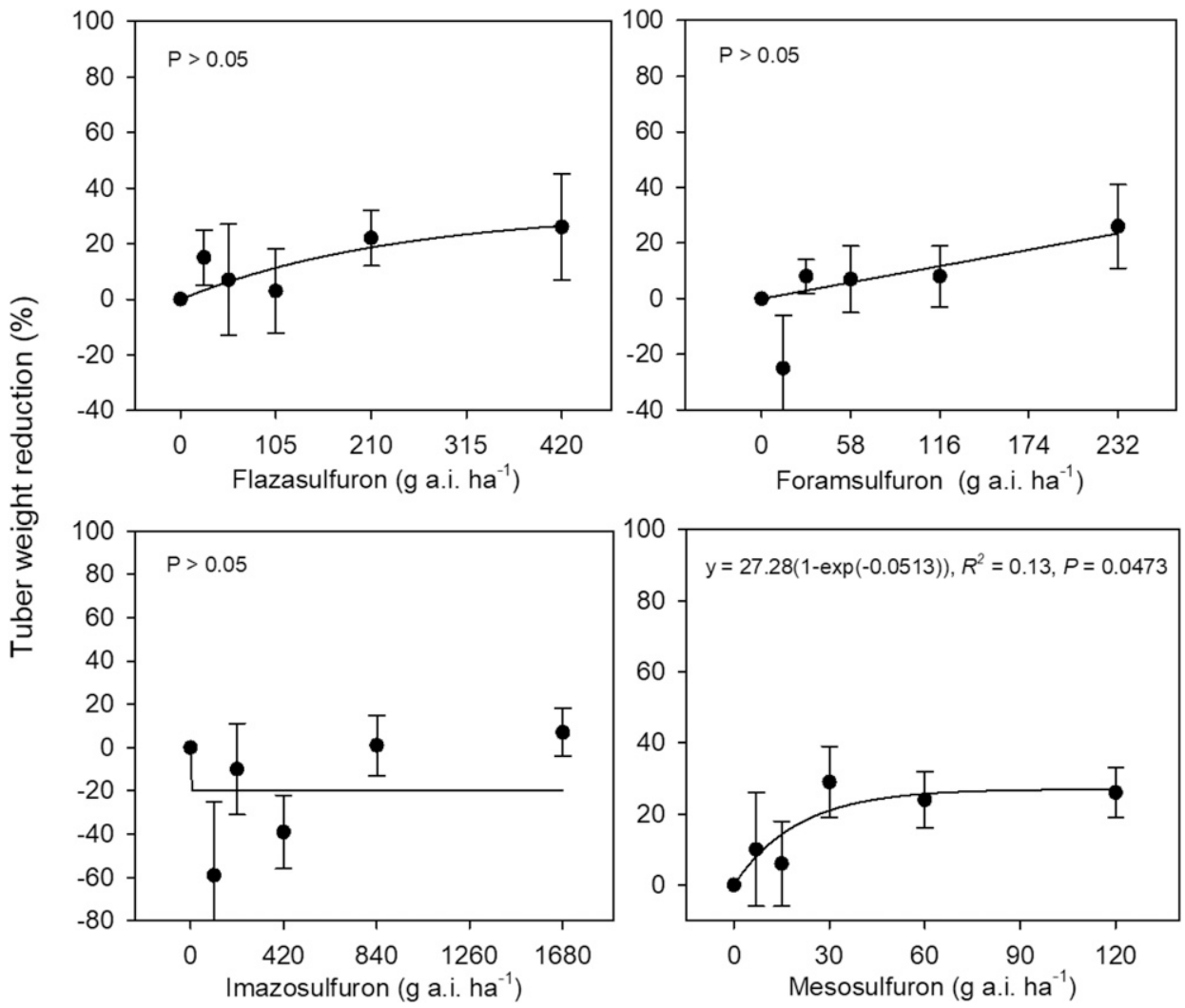

Fig. 8. Percent caladium 'Florida Fantasy' tuber weight reduction at 8 weeks after applications of flazasulfuron, foramsulfuron, imazosulfuron, and mesosulfuron in two combined greenhouse experiments in Balm, FL. Results were pooled over experimental runs. Means represent the average of eight observations. Vertical bars represent SES $(n=8)$. $P$ value above 0.05 did not achieve a significant nonlinear relationship. Caladium tuber weight $( \pm \mathrm{SE})$ of nontreated control measured $31.3( \pm 3.0) \mathrm{g} /$ plant at 8 weeks after herbicide applications. 
rates of glyphosate ranging from 1.8 to $36 \mathrm{~g}$ a.e./ha promoted the growth of maize (Zea may L.), soybean [Glycine $\max (\mathrm{L}$.$) Merr],$ rose gum (Eucalyptus grandis Hill ex Maiden), Caribbean pine (Pinus caribea L.), and benghal dayflower (Commelia benghalensis L.).

We concluded that both caladium cultivars, Florida Cardinal and Florida Fantasy, are highly tolerant to imazosulfuron. POST applications of imazosulfuron do not cause adverse effect on caladium growth and tuber production. However, POST applications of flazasulfuron, foramsulfuron, and mesosulfuron may significantly injure caladium, stunt plant growth, reduce foliage production, or decrease tuber yield. Moreover, susceptibility varied between cultivars and tuber growth of 'Florida Cardinal' was substantially more susceptible to flazasulfuron, foramsulfuron, and mesosulfuron compared with 'Florida Fantasy'.

\section{Literature Cited}

Bell, M.L., G. Wilfret, and D.A. DeVoll. 1998. Survey of caladium tuber producers for acreage of cultivars grown. Proc. Fla. State Hort. Soc. 111:32-34.

Bunnell, B.T., R.D. Baker, L.B. McCarty, D.W. Hall, and D.L. Colvin. 2003. Differential response of five bahiagrass (Paspalum notatum) cultivars to metsulfuron. Weed Technol. 17:550-553.

Burton, J.D., E.P. Maness, D.W. Monks, and D.K. Robinson. 1994. Sulfonylurea selectivity and safener activity in 'Landmark' and 'Merit' sweet corn. Pestic. Biochem. Physiol. 48:163-172.

Cai, X., Z. Cao, S. Xu, and Z. Deng. 2015. Induction, regeneration and characterization of tetraploids and variants in 'Tapestry'caladium. Plant Cell Tissue Organ Cult. 120:689-700.

Cao, Z. and Z. Deng. 2017. De novo assembly, annotation, and characterization of root transcriptomes of three caladium cultivars with a focus on necrotrophic pathogen resistance/ defense-related genes. Intl. J. Mol. Sci. 18:712.

Cao, Z., Z. Deng, and M. Mclaughlin. 2014 Interspecific genome size and chromosome number variation shed new light on species classification and evolution in caladium. J. Amer. Soc. Hort. Sci. 139:449-459.

Cao, Z., S. Sui, X. Cai, Q. Yang, and Z. Deng. 2016a. Somaclonal variation in 'Red Flash' caladium: Morphological, cytological and molecular characterization. Plant Cell Tissue Organ Cult. 2:269-279.

Cao, Z., S. Sui, Q. Yang, and Z. Deng. 2016b. Inheritance of rugose leaf in caladium and genetic relationships with leaf shape, main vein color, and leaf spotting. J. Amer. Soc. Hort. Sci. 141:527-534.

Cao, Z., S. Sui, Q. Yang, and Z. Deng. 2017. A single gene controls leaf background color in caladium (Araceae) and is tightly linked to genes for leaf main vein color, spotting and rugosity. Hort. Res. 4:16067.

Cedergreen, N. 2008. Herbicides can stimulate plant growth. Weed Res. 48:429-438.

Dastgheib, F., R. Held, and S. Namjou. 1994. The mechanism of differential response of wheat cultivars to chlorsulfuron. Weed Res. 34:299-308.

Deng, Z. 2012. Caladium genetics and breeding: Recent advances. Floric. Ornam. Biotechnol. 6:53-61.

Deng, Z., F. Goktepe, and B.K. Harbaugh. 2008. Inheritance of leaf spots and their genetic relationships with leaf shape and vein color in caladium. J. Amer. Soc. Hort. Sci. 133:78-83.

Deng, Z. and B.K. Harbaugh. 2006. Independent inheritance of leaf shape and main vein color in caladium. J. Amer. Soc. Hort. Sci. 131:53-58.
Gilreath, J.P., B.K. Harbaugh, and D. Bates. 1994. Preemergence herbicides for caladiums. Proc. Fla. State Hort. Soc. 107:211-215.

Gilreath, J.P., B.K. Harbaugh, and C. Lott. 1985. Chemical weed control in caladiums grown in organic soil. Proc. Fla. State Hort. Soc. 98:107-110.

Deng, Z., B. Harbaugh, R. Schoellhorn, and R. Andrew. 2005. 2003 Survey of the Florida caladium tuber production industry. Fla. Coop. Ext. Serv. Inst. Food Agr. Sci. 2 Nov. 2017. $<$ http://edis.ifas.ufl.edu/EP258>.

Deng, Z., B.K. Harbaugh, and N.A. Peres. 2016. Caladium cultivars cosmic delight, fiesta, and hearts desire. HortScience 51:766-771.

Gowda, P.R. and C. Prakash. 1998. Herbicide glyphosate at sublethal concentrations enhances somatic embryo development in sweetpotato (Ipomoea batatas L.). Current Sci. 75:508-510.

Miranda, B.D. and B.K. Harbaugh. 2003. 'Florida Moonlight'-A white fancyleaved caladium for pots and shady landscapes. HortScience 38:635-637.

O'sullivan, J., R.J. Thomas, and W.J. Bouw. 1998. Tolerance of sweet corn (Zea mays) cultivars to rimsulfuron. Weed Technol. 12:258-261.

Pornprom, T. and J.Y. Pyon. 1999. Primisulfurontolerant pepper: A biochemical basis of tolerance. Kasetsart. J. (Nat. Sci.) 17:325-333.

Scudder, W.T. 1961. Controlling annual weeds in caladiums on Florida peat soils. Proc. Southern Weed Sci. Soc. 14:164-174.

Velini, E.D., E. Alves, M.C. Godoy, D.K. Meschede, R.T. Souza, and S.O. Duke. 2008. Glyphosate applied at low doses can stimulate plant growth. Pest Mgt. Sci. 64:489-496.

Webster, E.P. and J.A. Masson. 2001. Acetolactate synthase-inhibiting herbicides on imidazolinonetolerant rice. Weed Sci. 49:652-657.

Wiedman, S.J. and A.P. Appleby. 1972. Plant growth stimulation by sublethal concentrations of herbicides. Weed Res. 12:65-74. 